\title{
OBSERVANCE OF HUMAN RIGHTS AS AN ELEMENT OF SHAPING THE POSITION OF THE EUROPEAN ENTERPRISE IN THE KNOWLEDGE-BASED ECONOMY
}

\author{
Kinga Machowicz*
}

\begin{abstract}
The goal of the article is to determine the role played by observance of human rights in shaping the position of the European enterprise in the knowledge-based economy. It has been assumed that the condition most expected by an entrepreneur is to achieve a competitive advantage. The concept of observance of human rights in conducting business activities is connected with business ethics and the idea of corporate social responsibility, while economic well-being can be achieved in the conditions of a knowledge-based economy. One of the conditions for the survival and development of the employer conducting business activities in the knowledge-based economy is to effectively motivate employees to reveal their knowledge and use it in practice. Non-financial motivation may involve the feeling of identification with the employer.
\end{abstract}

Keywords: human rights, democracy, innovations, knowledge based-economy 


\section{INTRODUCTION}

For some years social sciences have witnessed an increasingly evident tendency for investigating phenomena in interdisciplinary approaches. Economy no longer sees people and their rights in terms of the same capital as the financial or real capital. At the same time there is no doubt that even now business activities would not be possible without human participation. Taking the foregoing observations into account, it should be said that the objective of the article is to determine the role played by observance of human right in shaping the position of the European enterprise in the knowledge-based economy. It has been also assumed, based on the universal paradigm in social sciences, that the condition that is most expected by entrepreneurs conducting their business activities in Europe is the achievement of a competitive advantage. This article has been prepared based mainly on the method of institutional-legal analysis, the critical analysis of literature, including literature referring to the judicial decisions of the European Court of Human Rights.

\section{THE CONCEPT OF CORPORATE SOCIAL RESPONSIBILITY VERSUS} HUMAN RIGHTS PROTECTION IN THE COUNCIL OF EUROPE'S SYSTEM

The CSR concept shows that behaviors connected with the running of enterprises have a strong impact on the condition of the natural environment, human relations at the workplace, personality development, and on the proportions of time devoted to work and the employee's free time. At the same time, the norms of human rights protection also belong to some of the so-called specific norms of business ethics. That is why one of the elements of the CSR concept is the inclusion of legal responsibility in its scope ${ }^{1}$. The CSR concept has gained a new dimension because, without leaving the spheres of practice and scientific considerations, it also spreads to the normative sphere. The links of this idea with the protection of human rights are more and more noticeable. In the coming years the CSR

1 Krzysztof Kietliński, Victor Martinez Reyes and Tadeusz Oleksyn, Etyka w biznesie i zarządzaniu (Cracow: Oficyna Ekonomiczna, 2005), 132-160. 
concept will also continue to be endowed with legal sanctions at different levels. States can change their legislation. The practice of administrative and judicial authorities may certainly take into account the interpretive CSR context when applying ratified international agreements. That is why business entities are facing the not entirely voluntary implementation of CSR principles.

In a democratic state the behaviors of entrepreneurs translate into the implementation of both the first generation of human rights (inter alia personal rights), the second (economic, social and cultural rights) and the third generation of human rights (solidarity rights - collective rights vested in the public). Conducting business activities most often involves the questions of property protection (including intellectual property) but also the observance of such human rights and freedoms as the prohibition of slavery or forced labor, right to privacy, and freedom of expression. It is moreover recognized that property rights as first-generation human rights can be effectively protected by the Council of Europe's system. This stems from the requirement of ensuring an effective protection mechanism for human dignity at the level of protection of an individual's material existence ${ }^{2}$.

\section{INTELLECTUAL PROPERTY AS A HUMAN RIGHT AND THE KNOWLEDGE-BASED ECONOMY}

The conduct of economic activities in businesses that use modern technologies requires that intellectual property rights be respected. An entrepreneur who implements innovations should consider the justifiability of applying first of all for intellectual property protection. Having secured such protection, the entrepreneur prevents competitors from legally and gainfully utilizing the solutions developed in his/her enterprise even if these solutions are already within reach of the competitors. The entrepreneur, exercising his/her human rights, thereby places him/herself in a better position in the market because the ECHR accorded to intellectual property the protection of the exercise of property rights and the peace-

2 Krzysztof Orzeszyna, Michał Skwarczyński and Robert Tabaszewski, Prawo międzynarodowe praw cztowieka (Warsaw: Wydawnictwo C.H. Beck, 2020), 325. 
ful use of property. In judicial decisions the concept of property is interpreted broadly enough to be applied to (explainable) financial profits of specific entities ${ }^{3}$. Moreover, the ECHR notices the wide impact of innovation policy on the human rights system, which may in turn lead to the conclusion that the Court's future decisions in this area will shape the regional development of intellectual property. Although the Court's judicial decision-making depends on the complaints filed by citizens, yet as a result of the settlement of this matter, an essential turnabout can be observed in the decisions by this body that significantly changes the stance of the Council of Europe's agencies on cases concerning intellectual property. For while the Court was initially reluctant to engage in considerations on legal protection standards in this area, then as a result of the decision in the case in question it paved its way, as it were, to setting appropriate standards in the future. It can thus be expected that industrial property assets will continue to be the subject of the Court's interest and its decisions will set the limit to their protection and the rules of settling the collision with other convention-protected interests ${ }^{4}$.

The concept of the knowledge-based economy has in turn been defined in literature many times. It is emphasized that it is the economy based on knowledge resources and the use of knowledge potential, i.e. the elements that become strategic factors of its development. The understanding of how people produce new products and knowledge that enables effective and efficient operation is regarded as the most important problem in the knowledge-based economy 5 .

The ability to create and acquire knowledge and to use it effectively contributes to generating innovation, achieving a competitive advantage

3 Łukasz Duda, and Jakub Kociubiński, "Realizacja ochrony własności w Europejskiej Konwencji Praw Człowieka na podstawie orzeczenia Lithgow i inni,” Wroctawskie Studia Erazmiańskie 3 (2009): 235.

4 Mariusz Załucki, "Własność przemysłowa w Europejskiej Konwencji Praw Człowieka. Wokół granic monopolu eksploatacyjnego i nowych standardów ochrony," Zeszyty Naukowe Uniwersytetu Jagiellońskiego. Prace z Prawa Wtasności Intelektualnej 1 (2018): 138-148.

5 Elżbieta Skrzypek, "Kapitał intelektualny jako podstawa sukcesu organizacji w społeczeństwie wiedzy," in Wiedza w gospodarce, spoteczeństwie i przedsiębiorstwach: pomiary, charakterystyka, zarządzanie, ed. Elżbieta Skrzypek, and Krzysztof Piech (Warsaw: Instytut Wiedzy i Innowacji, 2007), 73. 
and economic success ${ }^{6}$. In the conditions of the knowledge-based economy the achievement of a competitive advantage is often associated precisely with innovations. According to the OECD, innovation is defined as "the implementation of a new or significantly improved product (good or service) or process, a new marketing method, or a new organizational method in business practices, workplace organization, or external relations" ${ }^{\text {" }}$. The basic types of innovation are: product, process, organizational and marketing innovation. Out of these types it is first of all marketing innovations that may impact on the exercise of personal human rights. Marketing innovations involve the implementation of new methods within the four basic elements of marketing activity: product design, selling and distribution, promotion, and pricing strategy. Unlike product innovations, marketing innovations do not have to involve changes of the functional and utilitarian characteristics of products, they may concern only the improved perception of products by customers ${ }^{8}$, or, in some way, influence the purchase decisions that are part of the customer's private sphere.

The studies on innovation and the state's innovation policy present innovations as one of the key factors of the competitive advantage of enterprises and economies. According to Porter, enterprises are able to achieve a competitive advantage owing to successes in implementing innovative solutions. Hamel and Prahalad assume that the creation in an enterprise of key competencies allows gaining a lasting competitive advantage since the pace of social changes that are the source of new needs and new domains is subject to constant growth and the formerly applied ways are not able to ensure the long-term success of an enterprise. Consequently, entrepreneurs should seek to base their successes on new products and services?

6 Piotr Stożek, "A Spatial Analysis of the Knowledge-Based Economy in Poland," Comparative Economic Research 17(4) (2014): 222.

7 OECD/Eurostat, Oslo Manual, Guidelines for Collecting and Interpreting Innovation Data, Paris: OECD Publishing, 2005, 48.

8 OECD/Eurostat, Oslo Manual, Guidelines for Collecting and Interpreting Innovation Data, Paris: OECD Publishing, 2005, 50-55.

9 Krystyna Poznańska, "Innowacyjność jako źródło przewagi konkurencyjnej polskich przedsiębiorstw," Materiaty i Prace Instytutu Funkcjonowania Gospodarki Narodowej 82(LXXXII) (2002): 65-79. 
The vague concept of competitive advantage and the multitude of elements that may at least potentially make up this advantage, combined with descriptive scientific theories, can, from the standpoint of economic practice, translate at least into the identification of elements available to a specific entrepreneur. This identification should subsequently result in the development and implementation of a situation-specific strategy for achieving a competitive advantage in the market. The simultaneous adoption of this manner of conduct by many business entities can bring about diverse results. In the present determinants of the economy it is difficult to imagine a variant in which only one enterprise will achieve an advantage. Rather, it will be a group of enterprises in a similar situation, better than the other competitors. The more so that by conducting a competent law-making policy the state prevents the extreme form of achieving a competitive advantage, i.e. the monopolization of the market. Consequently, taking measures to establish one's competitive advantage may de facto simply be a condition for one's mere survival in the market.

Product innovations involve the introduction of new or significantly improved goods and services with regard to their characteristics or applications. These embrace significant improvements regarding technical specifications, components and materials, built-in software, ease of use or other functional features. A product innovation is also a new application of a product and an improved way of providing a service. Product innovations can also be created based on any kind of intellectual property, or even a combination of its kinds - in one product there may co-exist inventions, functional design and/or topographies of integrated circuits; its external form can be an industrial designer product, and the whole can be given a trademark. Furthermore, the adopted solutions can be assessed in the context of copyright. In practice, assessing which products are creative encounters objective difficulties: "There remains, however, the area of the so-called semantic shadow, or the collection of works that may but not always will be recognized as the object of copyright. The stability of definition, and thereby legal certainty, is weakened by the constant development of science (including technologies that support the creative process; consequently the factor of the author's creative contribution is sometimes 
challenged)" ${ }^{10}$. For a work to function as industrial property, it has to satisfy the statutory requirements imposed on this kind of property. If a work does not have trademark distinctiveness, it will not be able to be for example a trademark ${ }^{11}$.

\section{THE IMPORTANCE OF OBSERVANCE OF PERSONAL AND ECONOMIC HUMAN RIGHTS FOR SHAPING THE POSITION OF AN ENTERPRISE IN THE MARKET}

Human rights are seen through the prism of the personal dignity of the individual human being. This interpretation ensures at least the relative priority of human rights over taking care of the economic development of a country. It is relative because one of the rights - the right to private life - may be restricted on account of the need to protect the economic well-being of a country although at the same time no restrictions may infringe the essence of human rights. The role of the bodies that ensure the execution of treaties-mandated obligations amounts to verifying whether the establishment of originally more rigorous domestic criteria for the possibility of limiting human rights comply in practice with at least the international minimum standard of protection. These agencies do not, however, have the powers to assess whether the State authorities comply with the legislation.

The minimum protection standards are set first of all by the provisions of the International Covenant on Civil and Political Rights ${ }^{12}$ and the European Convention on Human Rights and Fundamental Freedoms ${ }^{13}$. The latter international convention is a basal treaty presenting

10 Daria Katarzyna Gęsicka, “Wykładnia pojęć w prawie autorskim,” Zeszyty Naukowe Uniwersytetu Jagiellońskiego. Prace z Prawa Wtasności Intelektualnej 3 (2012): 69.

11 Jakub Kępiński, "Czy znak towarowy może być utworem?,” Ruch Prawniczy, Ekonomiczny i Socjologiczny 77(2) (2015): 182.

12 International Covenant on Civil and Political Rights of 19 December 1966.

13 Council of Europe, European Convention on Human Rights and Fundamental Freedoms, Rome, 4 November 1950 as amended by Protocols Nos. 11 and 14 supplemented by Protocols Nos. 1, 4, 6, 7, 12, 13 and 16, ETS No. 5: ETS No. 009, 4: ETS No. 046, 6: ETS No. 114, 7: ETS No. 117, 12: ETS No. 177. 
a cross-sectional approach to personal human rights and to voting rights. The regional protection system is complemented by conventions with a narrower objective scope. In contrast, the enacted amended Chapter of Fundamental Rights ${ }^{14}$ turned out to be the enriched reflection of standards developed within the Council of Europe. In the European Union there is indeed the impressive human-rights legal framework which coexists with constitutional traditions and the institutions of EU Member States ${ }^{15}$. With the passage of time, the framework will have to be filled with practice.

The right to private life is a concept that cannot be said to have been exhaustively defined in the statutory law or in judicial decisions or literature. Its constituent elements include inter alia the right to maintain one's psychophysical identity, to personality development, the right to family life of those gainfully employed, or the right to secrecy of correspondence. An element of the right to privacy is also professional activity and running businesses because professional life is a sphere of human activity in which interpersonal contacts are developed ${ }^{16}$. On the other hand, the sphere of privacy of the entrepreneur-employer comprises first of all business/trade secrets. Even the right that is apparently inseparably and exclusively associated with natural persons can, under specific circumstances, be exercised by legal persons that demand respect for good reputation, for their registered office, branches or other business premises ${ }^{17}$.

The conduct of business activities is often more effective by utilizing cooperation and exchange of experiences understood as emanating from the freedom of expression and freedom of association. The foundation of any human communication is the freedom of expression. The essence of this freedom entails the right to express one's views and to gain and disseminate information. However, the freedom of expression is not absolute, which means that it can be limited on account of the protection of

14 Charter of Fundamental Rights of the European Union (consolidated version), OJEU C 202 of 7 June 2016.

15 Michael O’Flaherty, "Ochrona praw człowieka w dzisiejszej Europie," Ruch Prawniczy, Ekonomiczny i Socjologiczny 79(1) (2017): 50.

16 ECHR Judgement of 16 December 1992. Case Niemietz v. FRG, application no. 13710/88, A. 251-B.

17 ECHR Judgement 16 April 2002. Case Stés Colas Est et al. v. France, Chamber II, application no. $37971 / 97$. 
other values and interests. From the perspective of the issues discussed in the present study, this is first of all the protection of personal interests of superiors, subordinates and associates. The exercise of the freedom of expression is therefore accompanied by responsibility in legal and ethical terms. This responsibility is not, however, tantamount to the prohibition to express disapproval or controversial views. In turn, the respect for the freedom of association of entrepreneurs is simply characteristic of a democratic government: "Among the many justifications for protecting freedom of speech and association, the argument from democracy is perhaps the most influential one"18. In a democratic system, one of the legally admissible goals of association can by all means be the intention to conduct business activities. The prohibition of slavery or forced labor in the development of labor relations is manifested on the other hand in diverse ways. This is protection both at the level of ratified international agreements, EU law, and domestic law. These detailed regulations in the framework of national law may refer to guarantees of labor protection, the minimum wage level, the right to safe and hygienic working conditions, the right to holidays specified by law, the right to an annual paid leave, and statutory maximum working time standards. The observance of these rights can be used to create the entrepreneur's positive image, which may indirectly result in building a competitive advantage because it may profitably translate into purchasing decisions taken by consumers. However, the role of the observance of human rights in building this advantage is most noticeable only in the context of consequences of the violation of these rights.

\section{CONSEQUENCES OF VIOLATION OF HUMAN RIGHTS}

A democratic state, when performing its role as a guarantor of human rights (also exercised in the economic sphere) has, by shaping the legislation, to appropriately ensure a balance in the exercise of these rights by different entities in different spheres of human activity because an individ-

18 Stefan Sottiaux and Stefan Rummens, "Concentric democracy: Resolving the incoherence in the European Court of Human Rights' case law on freedom of expression and freedom of association," International Journal of Constitutional Law 10(1) (2012): 125. 
ual cannot have rights that are merely illusory. Illusory protection would follow from norms that would not be reflected in practice whereas, under the accepted international standards, the protection of rights and freedoms cannot be illusory but actual and effective ${ }^{19}$.

A measurable form of protection is therefore the possibility of applying legal measures in the case of the violation of the entrepreneur's interests. In economic reality, the obtaining of ex post protection most often entails financial compensation. It may not necessarily allow the injured person to have all image losses compensated for but it may influence violators strongly enough to prevent their unlawful actions. And if the violator is the employer, such a situation is unimaginable in the sectors with the employee market. In other sectors of the economy a lot depends on the level of assertiveness of employees and former employees. They are able to take appropriate legal steps to protect employee rights or personal interests. Furthermore, legal measures based on the freedom of expression and at the same time launched in the media on an adequately large scale can result in reducing the consumers' interest in goods or services offered by a given entrepreneur. And this may cause a discernible decrease in income. In any case, business activity deliberately based on the violation of human rights in a democratic state should also start a cause-and-effect sequence that will, through the necessity of paying compensation and a decrease in income, force the violator to terminate his/her business activity.

\section{CONCLUSIONS}

As the present review of human rights exercised in the field of economy shows, the concept of the respect for/observance of human rights began to be combined with business ethics, the idea of corporate social responsibility, when it was found that the so-called wild capitalism is not the right means to develop entrepreneurship and does not thereby achieve economic well-being. In contrast, economic well-being can be achieved

19 ECHR Judgement of 7 July 1989. Case Soering v. United Kingdom, application no. $14038 / 88$, A. 161 . 
in the conditions of a knowledge-based economy. Moreover, assuming that the fundamental goal of entrepreneurs' activities is to develop their enterprises, which determines survival in the market, the respect for human rights even becomes part of business activity. It is possible to achieve the fundamental goal of survival when employees identify with the employer's objectives and manner of operation. Identification takes place the easier the more the employees are convinced that they can exercise their rights at the workplace. Identification is, moreover, indispensable so that employees willingly revealed the results of all activities executed thanks to their knowledge. At present, one of the conditions for the survival and development of the enterprise is to effectively motivate employees to reveal their knowledge and to apply it in practice. It is already taken for granted that employees are strongly motivated by financial incentives. In the conditions of competition between entrepreneurs such comparable motivational financial incentives can be offered by at least several potential employers. However, that which will influence the employee's identification with his/her employer is actually likely to come from non-financial factors. The emphasis on the role of trust and individual approach to the employee, as well as the practice of rewarding depending on the results of work, competence or skills stem from the rather seldom verbalized assumption of human dignity and the need to respect the individual's natural rights. Cases of violation of human rights may in turn start legal proceedings for responsibility implying financial burdens that are large enough to necessitate even the cessation of business. That is why the observance of human rights has a significant, multifaceted and positive impact on the position of the enterprise operating in the knowledge-based economy. The problems presented in this study can certainly be examined only from the separate angles of the industrial property law, labor law or civil law. However, the omission of the context of man's role and position in the discussion on the legal situation of entrepreneurs conducting business activities in the conditions of knowledge-based economy would overly narrow down the research area. 


\section{REFERENCES}

Duda, Łukasz, and Jakub Kociubiński. "Realizacja ochrony własności w Europejskiej Konwencji Praw Człowieka na podstawie orzeczenia Lithgow i inni." Wroctawskie Studia Erazmiańskie 3 (2009): 234-252.

Gęsicka, Daria Katarzyna. "Wykładnia pojęć w prawie autorskim.” Zeszyty Naukowe Uniwersytetu Jagiellońskiego. Prace z Prawa Wtasności Intelektualnej 3 (2012): 66-77.

Kępiński, Jakub. "Czy znak towarowy może być utworem?.” Ruch Prawniczy, Ekonomiczny i Socjologiczny 77(2) (2015): 177-191.

Kietliński, Krzysztof, Victor Martinez Reyes, and Tadeusz Oleksyn. Etyka w biznesie i zarzadzaniu. Cracow: Oficyna Ekonomiczna, 2005.

OECD/Eurostat. Oslo Manual, Guidelines for Collecting and Interpreting Innovation Data, Paris: OECD Publishing, 2005.

O’Flaherty, Michael. “Ochrona praw człowieka w dzisiejszej Europie.” Ruch Prawniczy, Ekonomiczny i Socjologiczny 79(1) (2017): 49-57.

Orzeszyna, Krzysztof, Michał Skwarczyński, and Robert Tabaszewski. Prawo międzynarodowe praw cztowieka. Warsaw: Wydawnictwo C.H. Beck, 2020.

Poznańska, Krystyna. "Innowacyjność jako źródło przewagi konkurencyjnej polskich przedsiębiorstw.” Materiaty i Prace Instytutu Funkcjonowania Gospodarki Narodowej 82(LXXXII) (2002): 65-79.

Skrzypek, Elżbieta. "Kapitał intelektualny jako podstawa sukcesu organizacji w społeczeństwie wiedzy." In Wiedza w gospodarce, spoteczeństwie i przedsiębiorstwach: pomiary, charakterystyka, zarządzanie, edited by Elżbieta Skrzypek, and Krzysztof Piech, 73-87. Warsaw: Instytut Wiedzy i Innowacji, 2007.

Sottiaux, Stefan, and Stefan Rummens. "Concentric democracy: Resolving the incoherence in the European Court of Human Rights' case law on freedom of expression and freedom of association." International Journal of Constitutional Law 10(1) (2012): 106-126.

Stożek, Piotr. "A Spatial Analysis of The Knowledge-Based Economy In Poland." Comparative Economic Research 17(4) (2014): 221-236.

Załucki, Mariusz. "Własność przemysłowa w Europejskiej Konwencji Praw Człowieka. Wokół granic monopolu eksploatacyjnego i nowych standardów ochrony." Zeszyty Naukowe Uniwersytetu Jagiellońskiego. Prace z Prawa Wtasności Intelektualnej 1 (2018): 138-148. 